\title{
Defining National Memories: The Cases of Popular Rebellions in Ireland and Québec
}

\author{
Christophe Davis \\ York University
}

\begin{abstract}
While studies on nations and nationalism have brilliantly demonstrated the influence of collective memory on national development, few studies have examined the reciprocity of this relationship. This article is therefore concerned with the laborious processes of memorizing the founding myths of both the Irish and Québécois nations. Indeed, while today the rebellion of 1798 in Ireland and those of 1837-1838 in Québec are central to their respective processes of identity-building, it has not been a calm process; the 1798 rebellion was buried in collective amnesia for almost a century and in Québec, the Patriotes rebellions have constantly moved in and out of collective memory. I argue, in this article, that the unstable definition of both nations harmed the process of remembrance. I am therefore interested in the long and conflicting journey that has enabled the Irish and Québécois nations to define themselves, respectively, by their religion and their language. Through a historiographical analysis of the speeches from several leaders of these two nationalist movements, this article shows how nations define and redefine themselves and how memories are also altered to meet those changes.
\end{abstract}

\section{Keywords}

nation-building; remembrance; rebellions; Ireland; Québec; structural critical discourse analysis

\section{Introduction}

In our contemporary society, the practices of commemoration and (re) memorialization are an increasing concern for public authorities. Discourses on the ancestors, the predecessors and the tradition itself are used to offer political programs a circumstantial and dated legitimacy. As Jan Kubik and Michael Bernhard $(2014,11)$ mentioned: "History ... is always made in the present." Indeed, as I shall demonstrate, historical events, used as national myths, are constantly reimagined and historiographically altered to remain harmonious with the evolving nature of the nation.

\footnotetext{
* Christophe Davis, Ross Building South, Room 672, 4700 Keele Street, Toronto (ON), Canada, M3J 1P3; cdavis8@yorku.ca
} 
Through an analysis of the rebellion of 1798 in Ireland and the rebellions of 1837-1838 in Lower Canada/Québec, ${ }^{1}$ this analysis will show that the processes of memorialization of these events were harmed by the difficult processes of nation-building. While the rebellion in Ireland was kept out of public memory for almost a century, the rebellion in Québec has moved in and out of social amnesia, in accordance with the various shifts in the definitions of the French-Canadian and later Québécois nation. Therefore, how can we explain these important gaps in the Irish and Québécois projects of remembrance? By analyzing discourse of significant nationalist leaders, this article argues that the unstable definitions of their respective nations have made it difficult for these events to be swiftly commemorated.

\section{National Myths: Founding Rebellions}

The two rebellions were very similar in their objectives, unfolding, and repercussions. Both majoritarian populations sought to overcome British colonialism. Their mutual desire for freedom is all the more interesting knowing that both groups drew on each other and their respective memories to position themselves as a Catholic people within a Protestant-dominated empire (Bric 2016, 39).

More specifically, surrounding the context of the rebellions, both were responses to an unfair and corrupt political system, which was designed to assimilate the respective Catholic and French-speaking majorities. For instance, at the time, Ireland had an Anglican-minority-dominated parliament. The population was openly criticizing and denouncing the behavior of parliamentarians, who were too dependent on the patronage instituted for the benefit of British interests (Englefiel 1955, 59). Similarly, in Lower Canada, the powers of the representative Chamber of Assembly were counterbalanced by the London-appointed governor and its executive council (Ducharme 2009, 117). The lack of political representation, in addition to the many economical and social policies of assimilation, were therefore the main justifications for rebelling.

The two leaders of the rebellions, Theobald Wolfe Tone in Ireland and LouisJoseph Papineau in Lower Canada, routinely criticized their local institutions. However, faced with the intransigence of Westminster, both concluded that the complete independence of their respective territories was legitimate.

Wolfe Tone famously said: "It will be the interest as well as the duty of a national government to redress their grievances and to enlighten their minds.

1 In this article, "Québec" and "Lower Canada" are seen as interchangeable concepts, the former being the geographical continuation of the latter. 
The unnatural union between church and state, which has degradated religion into an engine of policy, will be dissolved. [...] To say all in one word, Ireland shall be independent. We shall be a nation, not a province; citizens, not slaves" (Wolfe Tone 1796, 18).

Papineau saw the situation similarly: "We have not mentioned the independence from the British Crown, but let us not forget that the destiny of the continental colonies is to separate from the metropolitan state when the unconstitutional actions of a legislative power residing in far country is unbearable"2 (Papineau (1837) 1998, 439).

In addition to the many similarities between these two events, I note that they were integrated into the collective memory in relatively similar ways. Indeed, both processes of memorialization were harmed by the swaying definition of their nations. In both cases, it took more than a century and specific conditions for the rebellions to be employed as a unifying memory. Yet, interestingly, in both cases under study, the rebellions have reached, over time, the status of the nation's founding event, despite these difficult processes of remembrance.

\section{National Memories between Culture and Discourses}

As Matthew Levinger and Paula Franklin Lytle (2001, 178) have demonstrated, every nation is, more or less, constructed on a similar frame that is composed of three elements (the glorious past, the degraded present, and the utopian future). This triadic structure functions as a highly effective rhetorical strategy for mobilization. The juxtaposition of diverse images from the community's past, present, and future conditions serve as the basis to socially develop belonging. Every nation has its own understanding of its distinct past, transmitted through collective memory, myths, and discourses, which may be historically accurate or not. It is the belief that these mnemonic constructs are shared by the members of the nation and create a sense of belonging so important in nationalism. Indeed, nations should be understood as communities of memory, in the sense that their members not only understand themselves as sharing similar traits, such as ethnicity, culture, or language, but as bound together by a common interpretation of a shared past that underpins their collective identity (Viggiani 2014, 15). Interestingly, the two rebellions under study have had difficulty being commemorated until their respective narratives could be described and politicized as a "glorious past," more than a century after the events.

2 My translation. 
Scholars have strongly established the impact of remembrance on national development (see, among others, Anderson ((1983) 2006; Hobsbawm (1983) 2012; Misztal 2003; Bergholz 2016). Antony Smith (1995, 18), leading this field, interestingly questioned: "Perhaps the central question in our understanding of nationalism should be the role of the past in the creation of the present." Smith's analysis did not, however, draw significantly from the rich body of literature about memory that has been appearing since the early 1990s. Smith's understanding of memory, focusing mainly on myths and ethnohistory, is "dated." Today, the interdisciplinary nature of memory studies has refined our understanding of memory processes and impacts (Rigney 2018, 242). In this vein, I use here the concept of "cultural memory," a term first coined by Jan Assmann and Jan Czaplicka in the 1990s (1995, 126). It is specifically concerned with the role of narrative in shaping the understanding of the past, the role of commemorations in transmitting those narratives, and the power of discourses to mobilize memories. This article expands on the theories developed by many ethnosymbolists, arguing that memory is also dependent on the evolution of nations and nationalism. Indeed, while the necessity of memory to national development processes is widely accepted today, few studies have been interested in the role that national development has on the processes of memorialization and remembrance. This article is interested in the latter relationship, in demonstrating how remembering is affected by changing national definitions.

To this end, this paper adopts the theories of cultural nationalism as presented by John Hutchinson (1987; 1994). He introduces postmodernist elements to the analysis of nationalism. More specifically, he focuses on the inherent multiplicity of voices found inside a given nation. He contends that these multiple discourses, by orienting themselves toward a common fund of symbols and memories, wind up reinforcing the nation as a whole. The vision of nations as unitary and autonomous societies is a myth: "there can be no final definition of a national identity" (Hutchinson 2004, 111), not because the nations are imaginary, invented, or dissolved into institutional practices, but because all nations are constituted around, and always contain, "rival symbolic repertoires" that indicate "different visions of the nation" (Hutchinson 2004, 87). Overall, I intend to demonstrate how, in accordance with Hutchinson, we can theorize cultural nationalism as an ongoing struggle over the definition and character of the nation, which hinders the processes of memorialization. The act of commemorating is complex, as it serves both contradictory ends and responds to diverse needs. It is, however, central to nation-building, identity-building, and state-building. Consequently, it is 
essential to pay more attention to the ways memorialization takes place, how memories evolve according to national developments.

To grasp the changing definition of the Irish and Québécois nations, I will employ structural critical discourse analysis (SCDA). This approach developed, in part, by Louis Althusser (1976), Roland Barthes (1966), and Michel Foucault ((1971) 2009), was introduced as a way to theorize the influence of ideology. Althusser was dedicated to defining a science of ideology, of which SCDA has been an essential component. To him, "social formations" are the reproduction of "imaginary formations" that are accessible through analyzing discourse (Althusser 1976, 91). Consequently, social practices and linguistic practices constitute one another, and societal power relations are established and reinforced through ideological language (Metzger 2019, 112). SCDA's main function is to capture and represent the semantic structure that underlies a discourse. Unlike categorical (or thematic) discourse analysis, it does not only analyze what is said explicitly; it goes beyond words and meaning. It allows a more in-depth analysis of the discourse and the underlying representations that structure it. Therefore, we can have a better understanding of how nationalists traced the boundaries of their nations, the evolution of the defining elements of both the Irish and Lower Canadian/ Québécois nations. In parallel to this SCDA, I will pay attention to the various projects of commemoration regarding the two rebellions. This dual analysis of discourses and commemorations will demonstrate that the process of integrating these historical events to the collective memory was hindered by the changing definition of their respective nations. Further, by comparing these two cases, this analysis makes an original contribution by providing a new comparative framework that can be used in further research on memory. Indeed, a comparative approach brings novelty to the is, as it helps overcome what Jan Kubik and Michael Bernhard $(2014,9)$ have identified as one of the gaps in studying memory: "the paucity of systematic comparative studies."

For Ireland, I will mainly analyze the discourses and contexts of Theobald Wolfe Tone and Daniel O'Connell to understand how each of these individuals has defined the Irish nation. To add depth to the argument, references to Father Patrick F. Kavanagh will also be made, since the commemorations of the rebellion were heavily based on his writing (Collins 1999, 36). As I will show, his religious framing of the rebellion went along with the changing nature of the Irish nation.

As for Québec, I will analyze discourses of Louis-Joseph Papineau, leader of the rebellions of 1837-1838. I will also present elements from Pierre Bourgault, who gave a new vocation to the Québec nationalist movement 
in the 1960s, which had taken refuge in religion and traditionalism during the reign of Maurice Duplessis. The confrontation between Catholicism and French language marked the national history of Québec and, in the end, impaired the memory of the rebellion.

\section{The Entrance into Social Amnesia}

\section{"Who Fears to Talk about 98:" The End of the Protestant Nation in Ireland}

Shortly before his death in 1862, the Archbishop of Armagh, Lord John George de la Poer Beresford said: "When I was a boy, the Irish people meant the Protestants; now it means the Roman Catholics" (quoted in Bartlett 1992, 343). Just like that, he summarized half a century of struggle and modifications regarding the definition of the Irish nation. Indeed, after 1860, the Catholic people of Ireland were identified with the Irish nation, and it seemed that there would be no place or role for Protestants inside this definition. Protestants, of course, could continue to describe themselves as Irish, but the term "Irish" was used as an adjective. The collective noun "The Irish," was reserved for Catholics (Bartlett 2014, 2). As I shall show in this section, this slow transformation from "an" Irish people to "the" Irish people would have important consequences for the remembrance of the 1798 rebellion, which was the triggering event of such a change.

In 1791, the Society of United Irishmen was founded upon the idea that parliamentary institutions in Ireland needed to be reformed. As seen earlier, England's negation of the Irish grievances initiated a movement toward more radical actions and complete independence of their island. They believed in a nation that would be civic, moving away from ethno-religious differences. As we can see form the society's 1791 pamphlet, in which Theobald Wolfe Tone, himself a Protestant, came to the defense of the Irish Catholics, wanting them to receive a similar quality of education; in this pamphlet, he clearly identifies the British empire as their political "enemy:"

They plunge them by law, and continue them by statute, in gross ignorance, and then we make the incapacity we have created an argument for their exclusion from the common rights of man! We plead our crime in justification of itself. If ignorance be their condemnation, what has made them ignorant? Not the hand of Nature, for I presume they are born with capacities pretty much like other men. It is the iniquitous and cruel injustice of Protestant bigotry, that has made them ignorant; they are excluded by law from the possibility of education; for I will not call the liberal connivance of the heads of our University, who suffer, perhaps by a strain on their strict duty, a few to smuggle a 
little of that learning, which is contraband to an Irish Papist, I will not, I say, allow that to be such an education as every Irishman has a right to demand. They cannot obtain degrees; those are paled in from them by oaths, those oaths of which they are so regardless, and, therefore, we find they do not enter our University. (Wolfe Tone 1791, 20-21).

As we see here, Wolfe Tone acknowledged that the Catholics of Ireland were harmed by "Protestant bigotry." This oath of allegiance to the English monarch symbolized an acknowledgment of Protestant superiority and a legitimization of their colonial system. It was, in sum, a way of assimilation that Wolfe Tone aimed to end through his rebellion.

Overall, in his numerous public appearances, Wolfe Tone challenged the definition of a Protestant Irish nation. For him, to be Irish had little to do with religion. It was rather with the land, the island of Ireland, liberal ideals of freedom, in addition to a rejection of British imperialism. Yet, the failed rebellion and the subsequent Act of Union of 1800, ironically brought religion to the forefront of Ireland's societal division.

It is in this context, where religion became an extremely salient issue, that in 1802, the first "historical analysis" of the rebellion was published: Memoirs of the Different Rebellions in Ireland. In it, Richard Musgrave, an ultra-Protestant ideologue, described the 1798 rebellion as "a conspiracy ... for the destruction of the Protestant Church” (Musgrave 1802, 14). This book's revisionism is, in part, to blame for burying the event in social amnesia, Catholics and Protestants refusing to recognize the alliance made with the other during the rebellion (Andrews 2006, 43). Nevertheless, we can say that Wolfe Tone's words, just like the rebellion itself, represented a turning point for the Irish nation, a new interpretation of what it meant to be Irish, and a change that would continue during the late 1820s with Daniel O'Connell.

\section{The Mouvement Patriotes and the Importance of French Language}

Johann Gottfried von Herder once asked: "Has a nation anything more precious than the language of its fathers?" (Quoted in Oakes 2001, 22). If this question is now mostly answered in Québec, it took more than 100 years for language to surpass religion as the main unifying vector of the Québécois identity. The process of memorizing the events of 1837-1838 in Québec has long been compromised by conflicting embodiments of the nation, torn between religion and language. Contrary to the Irish case, where the rebellion was plunged into social amnesia for more than a century, the Patriotes rebellions of 1837-1838 have moved in and out of Québec national myths. In fact, these memorial shifts have been so prominent that in a historiographical 
review of the rebellions, Jean-Paul Bernard $(1983,16)$ acknowledged the various legacies of its memory: "We thus have 'flavour of the day' patriots and patriots for everyone's tastes." ${ }^{3}$ Through this satirical comment, Bernard pointed out the difficult process of memorizing the rebellions, whose legacy was often modified in the course of history in order to remain in symbiosis with national development. Indeed, throughout the 20th century, the event gave rise to numerous and varied historical interpretations. In each of them, several research orientations, sources, and phenomena have been emphasized in order to support or minimize particular aspects of this turbulent episode in Québec history. In sum, it was constantly reworked and revisited, sometimes even exploited.

Just like in Ireland, the rebellion in Lower Canada started after demands for institutional reforms were frowned upon. In 1791, London decided its colonies in North America could each have a legislative assembly. However, for the French-speaking population, these measures were perceived as another assimilative policy. In addition, the unsuccessful constitutional reform measures proposed by the liberal French-speaking Parti Canadien led the party and the population to radicalize their political claims. In 1826, the party changed its name and became the Parti Patriote, at the request of its leader Louis-Joseph Papineau, in an effort of filiation with the American patriots who, them, defeated the British.

Faced with the intransigence of the British authorities, Papineau and other members of the mouvement patriotes wrote, in 1834, the 92 resolutions. Each of these 92 resolutions represented a direct request to Westminster, seeking more political power for the people of Lower Canada. By analyzing the discourses of the 92 resolutions and some speeches pronounced by members of the leaders of the mouvement patriotes, we can clearly see the importance they attributed to their language and their French heritage. For example, resolution number 52 goes as follows:

Resolved, That since a circumstance, which did not depend upon choice of the majority of the people, their French origin and their use of the French language, has been made by the colonial authorities a pretext for abuse, for exclusion, for political inferiority, for a separation of the rights and interests; this House now appeals to the justice of His Majesty's Government and of Parliament, and to the honour of the people of England; that the majority of the inhabitants of this country are in nowise disposed to repudiate any on of the advantages they derive from their origin and from their descent from the French nation, which, with regard to the progress of which it has been the cause in

3 My translation. 
civilization, in the sciences, in letters, and the arts, has never been behind the British nation, and is now the worthy rival of the latter in the advancement of the cause of liberty and of the science of Government; from which this country derives the greater portion of its civil and ecclesiastical law, and of its scholastic and charitable institutions, and of the religion, language, habits, manners and customs of the great majority of its inhabitants (quoted in Bédard 1869, 348-9). ${ }^{4}$

The patriots sought here to assert their belonging to a national entity of French origin and the right of this nation to enjoy recognition equal to that enjoyed by the English-Canadians. It is clear, when reading the other 91 resolutions, that the objective of the patriots was, ultimately, to promote the project of society that they believed was most apt to ensure their national development, perceived as being undermined by the constitutional institutions in place and by Britain's colonial empire. These national demands included maintaining the social and cultural institutions specific to Lower Canada, for which the French language was an essential component. As Augustin-Norbert Morin said (1825, 11): "Now, the most important and sacred of these is undoubtedly the one by which a people give the same names to things and the same signs to ideas," reiterating the importance of language in Québec national belonging. This national definition, which emphasizes democratic institutions, language, and culture, remained more or less stable until the signature of the British North America Acts (BNAA) in 1867. This new constitutional act established a federal system and over time, became understood in Québec as an acknowledgment of its French heritage, as one of the two "founding peoples of Canada." Therefore, protected by this new constitution and also by the mechanisms of a decentralized federal regime, French-Canadian nationalism plunged into la survivance. Indeed, after the conquest of 1763 and the failure of the rebellions, it was clear that the social, political, and economic opportunities for French-Canadians were harmed. The political leaders thus resigned themselves to a defensive posture, focused on the past, on survival. During this period, and until 1936, religion slowly but surely occupied an increasing amount of space in Québec society. However, as indicated by Mathieu Pigeon (2017), it was only during the reign of Maurice Duplessis that religion overthrew language as the main vector of Québec's collective identity. Religion was always a distinctive aspect of French Canada, but it was understood as one element, among others, deriving from France. Language remained the main distinctive feature from other ethnonational communities

\footnotetext{
4 My translation.

5 My translation.
} 
in North America, especially considering the successive waves of Irish and Scottish immigrants, who shared French-Canadians' Catholicism.

This period known as la survivance also amplified the national desire for commemorations, which allowed for the beginning of a process of memorializing rebellions. Not referring to large-scale commemorations, but at the start of the 20th century the state nonetheless funded certain monuments dedicated to the Patriotes in Montréal and in Saint-Denis-sur-le-Richelieu, place of the most important Patriotes victory during the 1837 rebellion (StJean 2009b, 55-8). In addition, Patriotes flags sometimes appeared on the floats of the French-Canadians' national holiday, thus associating their legacies with Québec's nationalist narrative.

\section{Catholic Nationalism, Rebellious Amnesia}

\section{Nation-Building through Catholicism in Ireland}

As mentioned, the Act of Union of 1800 harmed the Catholic position in the new institutional design known as the United Kingdom. The Anglican Church was to be recognized as the official Church of Ireland and more importantly, no Catholics were allowed to hold public office unless they renounced their religion through the oaths. The union solved none of the sectarian problems over land, religion, or politics and basically had no social dimension at all. The only thing the Act did, in the end, was increasing the sense of grievance among the Catholics (Hill 2001, 52). The Act of Union quickly became a liability as the message of Daniel O'Connell spread upon the Irish Catholics. As he said: "every man who feels with me proclaim, that if the alternative were offered him of Union, or the re-enactment of the Penal Code in all its pristine horrors, that he would prefer without hesitation the latter, as the lesser and more sufferable evil" (O'Connell 1828).

For O'Connell, the Protestants were colonizers and foreigners to the island and should not be able to rule over the Catholics. With his charismatic personality and his appealing message on emancipation, O'Connell quickly became the voice of Ireland's renewed cultural nationalism (Hutchinson 1987, 78). Moreover, Westminster did not devote much attention to its Irish colony and tardily realized the influence of Daniel O'Connell had started to gain. A tremendous process of politicization had begun among the Catholic peasantry and working class. A Catholic consciousness increased significantly, and a Catholic nation started to emerge, "shaped by history and the sense of the past, but also shaped by the realities of contemporary Irish life" (Bartlett 2014, 13). 
By the 1840s, O'Connell managed to organize what has become known as his "monster meetings," where more than 100,000 Catholics gathered in various locations to hear his talks about his vision of the Irish nation and his desire to repeal the Act of Union (McCaffrey 2015, 53-60). It was during such a gathering in 1843 that O'Connell said: "I want to make all Europe and America know it - I want to make England feel her weakness if she refuses to give the justice we the Irish requires - the restoration of our domestic parliament" (O'Connell 1843, quoted in McCaffrey 2015, 52). It is here that we see the real fracture between O'Connell's speech and that of other nationalist leaders who preceded him, including Theobald Wolfe Tone. Indeed, given the context in which the discourse takes place and the ideology underlying it, we can conclude that when O'Connell says "we the Irish", he refers to the Catholic population. By then, for O'Connell and his supporters, the Irish nation and Catholics were two terms for the same meaning (Bartlett 2014, 25).

However, the redefinition of Irish nationalism did not, in the beginning, lead to the memorialization of the 1798 rebellion. As it will be demonstrated later on, specific conditions, all linked to the newly formed nation, were necessary for the event to be publicly commemorated. Daniel O'Connell, today known as "The Liberator," which says a great deal about his place in the Irish collective memory, sought to distance himself from any form of revolutionary nationalism. Moreover, his discourse, gave few, if any, place to the Protestants. Therefore, remembering an event where Protestants and Catholics fought side by side would harm his message. That's why O'Connell always claimed no Catholics participated willingly in the 1798 rebellion: "In the county of Wexford, where the greatest part of the rebellion raged, there were no United Irishmen previous to the rebellion and there would have been no rebellion there if they had not been forced forwards by the establishment of Orange lodges and the whippings and torturing and things of that kind" (O'Connell 1841, quoted in Collins 2004, 10).

Moreover, the Catholic Church never approved of the rebellions, for its liberal ideals mostly, but also because of the links between Wolfe Tone and the French revolutionaries. Indeed, the rebellion of 1798 was greatly influenced by the French Revolution. The Church feared that acknowledging the rebellion would place them in a situation similar to the Catholic Church in France, post-1789 (Foster 2001, 87). O'Connell's discourse was a continuation, and extension of the Church's fear of being erased. 


\section{Maurice Duplessis: Québec's Religious Nationalism}

The emergent commemoration of the Lower-Canadian rebellion abruptly stopped after the provincial election of 1936, one year prior to the rebellion's centenary. Maurice Duplessis and his traditionalist-conservative party, L'Union Nationale, gained control of 76 out 90 electoral seats in the National Assembly of Québec, and his party would reign over Québec for 20 of the following 24 years. As mentioned, Maurice Duplessis wanted to revive Québec national pride. However, his nationalist revival built a different vision of the nation, where culture and language were no longer the main distinguishing factors. Rather, religion, traditionalism and ruralism occupied this place, as shown in the first two directives of the 1935 party manifesto: "What was the first law imposed on men with regard to life in society? The law imposed on men by nature, by God himself is to come together, to unite and to live in society." And later on, "What are the main rights that belong to every citizen? There are certain rights which are inherent in every citizen and which he cannot alienate himself; such is the right of life, that of seeking happiness, and of worshiping the Supreme Being" "(Union Nationale 1935). Between 1936 and 1959, we can say that religion played an enormous role in the population's daily life, in terms of education, health care, the state, and all sorts of private matters as well. Religion became a defining vector of Québec nationalism at the time. As this newspaper article of 1938 argues: "This same M. Duplessis bows before the Papal legate ... symbolically hands the keys of his Province to the representative of Rome" (Qulggin 1938, 6).

This renewed national definition impaired the memorialization of the rebellions. A good example of this was what happened to the painting L'Assemblée des six comtés, by the painter Charles Alexander. It represents one of the most notorious iconographies of the rebellion, where Papineau delivers a speech to its supporters. The province acquired this painting in 1930 and, in 1937, the year of the centenary, Duplessis transferred the artwork to the National Museum of Arts, where it was stored and forgotten for more than 50 years (St-Jean 2009a, 438). Duplessis's reign demanded new myths that would be more in line with the definition of the nation that was promoted at the time. The memory of the rebellion did not help to promote a Catholic nation, since the liberal ideals of the patriots contravened the religious conservatism imposed by the government of Duplessis. Therefore, other myths were promoted such as that of St. John the Baptist who had been, by then, officially declared the patron saint of the French-Canadians.

6 My translation. 


\section{Fixating the Nation: Remembering the Rebellion}

\section{The Approaching Centenary and the Necessity to Commemorate}

After O'Connell's death in 1847, a new chapter in Irish nationalism began. With the failure of O'Connell's repeal movement, and the terrible management of the great famine by Westminster, discourses on nationalism radicalized, and in 1858, the Irish Republican Brotherhood (IRB), the most important organized Irish paramilitary group of the 19th century, was founded. Moreover, the 1860s were also marked by increasing demands for commemoration from a new generation whose parents or grandparents fought in the rebellion and were seeing its memory erased. In sum, the late 1860s saw the conditions for remembering the 1798 rebellion coming together as revolutionary nationalism was growing once again, in addition to a new Catholic middle class that made explicit demands towards commemorating the events (Foster 2001, 70).

Even if the Catholic Church continued to be refractory to commemorations, in the face of the popular pressure, and most importantly, to avoid giving the IRB a free hand on commemorations, the Church allowed the publication of numerous books relating the history of 1798 , in order to adapt and shape the memory of the event (Collins 2004, 26). The most important of them was a story promoting "Faith and Fatherland," A Popular History of the Insurrection of 1798, published in 1870 by the Reverend Patrick F. Kavanagh (Foster 2001, 71). Focusing on County Wexford, the book portrayed the rebellion as a Catholic one, downplaying the role of the United Irishmen: "When Wexford stood at bay the United Irishmen were not to be found" (Kavanagh (1870) 1880, 171). Moreover, Father Kavanagh discredited the 1802 interpretations of Richard Musgrave: "whose veracity in almost every instance appears equally questionable” (Kavanagh (1870) 1880, 83). In sum, for Kavanagh, the Catholics were the true heroes of 1798 . As Collins $(2004,27)$ mentioned: "Kavanagh's version tells the story of the 'morally pure' Catholic peasantry of Wexford, led by their heroic priests, which fought bravely in defence of their homes and churches in the face of the utmost provocation of their sectarian tormentors."

Shortly after the publication of Father Patrick F. Kavanagh's book, and given the willingness to publicly commemorate the rebellion, his Catholic interpretation gave politicians a narrative that they could use in order to finally introduce the rebellion to public memory. In addition, the centenary was approaching and was seen as a great opportunity to unify and publicize the demands for more autonomy. Many "98 clubs" were founded across 
Ireland in order to commemorate the rebellion locally. In 1897, a National Commemoration Committee was put in place to manage the different projects and to provide a sort of national overview (Collins 2004, 29).

Yet again, the paramilitaries and the Church fought in order to control the narrative of these commemorations. Many Fenian organizations proposed monuments as tributes to the role and legacy of the Society of United Irishmen. Among them was planned a statue of Theobald Wolf Tone, to be erected in Dublin, and meant to be one of the biggest monuments of the centenary (Foster 2001, 77). However, because of Church opposition and because of Kavanagh's narrative, which downplayed the role of the United Irishmen, the statue was never built, as James Joyce famously states in Ulysses: "Five tallwhitehatted sandwichmen between Monypeny's corner and the slab where Wolfe Tone's statue was not" (Joyce (1922) 2013, 412).

Rapidly, the Catholic Church gained control over the commemorations. In County Wexford and Wicklow, for instance, Father John Murphy, who was immortalized and elevated to the status of a national hero in the work of Patrick F. Kavanagh, saw many of his portraits altered in the weeks preceding the beginning of the celebrations in order to add a Roman Catholic collar (Johnson 1994, 89), thus transforming a hero into a Catholic hero. Moreover, many of the official memorials designed by the artist Olivier Sheppard depicted the actors of the rebellion in peasant clothes rather than United Irishmen uniforms (Collins 1999, 40), again disassociating the narrative from the secular ideals of the United Irishmen and paramilitary. In sum, the late 19th century offered a set of conditions that were perfect for the introduction of the 1798 rebellion, a now-Catholic rebellion, into public memory.

\section{The Quiet Revolution and the Rehabilitation of Rebellious Memory}

In Québec, the 20 years following Duplessis's death in 1959 have been described as the "Quiet Revolution." Over this period, as Geneviève Zubrzycki $(2016,151)$ convincingly shows, the promotion of an alternative nationalism emerged as an aesthetic revolt against national religious symbols. With its successive liberal governments, Québec politics rapidly moved away from the Church narrative and renewed its aspiration to become an independent nation. A process accelerated, in part, by Pierre Bourgault, who founded, in 1966, the Regroupement pour l'Indépendance Nationale (RIN), the first openly sovereigntist party in the history of Québec, which drastically redefined Québec's nationalism. Bourgault was an ardent defender of the French language and a remarkable speaker. For example, in a public speech, referring to Québec Prime Minister at the time, Robert Bourrassa, Bourgault said: 
The prime minister says: "Even France is not unilingual French" which is stupid. France is unilingual French, as England is unilingual English, Sweden unilingual Swedish and Mexico unilingual Spanish. It is obvious that in France, one works in French, one earns his income in French, one governs in French, one studies in French and one spends his money in French. ... Which does not prevent a lot of French from speaking English, German, Chinese or Japanese. This does not prevent the French from having international relations, to trade with the rest of the world, to do international politics. The French, like the English, like the Swedes and the Mexicans, put themselves in a normal situation, they gave all the priority to the language of the majority. ... This is abnormal. No nation in the world accepts this situation except us. ... in our situation, while we are forced to speak the language of the minority, being bilingual is synonymous with slavery? (Bourgault 1966).

It is interesting to note that Pierre Bourgeault, and several other promoters of Québec independence, were questioning the norms regarding the language situation in Québec. By assigning the status of norm to speaking French in the province, Bourgeault came to conceive the nation through the language spoken by its members. As Joseph Yvon Thériault $(2007,117)$ demonstrated, the relationship of French-Canadians and later Québécois, to language is completely unique in the world. In the particular case of Québec during the subsequent colonial ventures, the French language did not carry the stigma of a colonizing language for French-Canadians; it first asserted itself as indigenous, and logically, in the 1960s, as a national language.

Through this national restructuration, patriotic memory and iconography became closely linked to the sovereigntist movement. One is often reminded, in fact, that struggles for independence are, in a way, a pursuit of the ideals defended by the Patriotes. However, after the failure of two referendums on Québec independence (1980 and 1995), the sovereigntist movement needed to be unified. As in Ireland, given the rehabilitation of the Patriotes, this unification was made through the memorial legacy of the rebellion. In 2001, nationalist Prime Minister of Québec Bernard Landry officially asked the National Assembly that the first Monday before May 25 of each year, a day used in all other provinces to celebrate Queen Victoria, becomes National Patriots' Day. He declared wanting to "emphasize the importance of the Patriots' rebellions of 1837-1838 for the recognition of our nation for its political freedom and for the establishment of a democratic government"

7 My translation.

8 My translation. 
(Landry 2001). Since 2002, celebrations have been organized every year to commemorate the battles of 1837-1838. Those festivities are still linked to the movement seeking the independence of Québec.

\section{Conclusion}

As demonstrated in this article, remembering, in a state-seeking nationalist context, is a political act. Memory is used to promote the nation and thus it becomes a national artifact. However, through this historiographical study of both nations' long and difficult processes of nation-building, we can see how national developments have impacted the processes of remembering the rebellions. By applying the tools and strategies of SCDA to the nation-building processes, we see that the nation is an always-changing object, echoing the findings of many constructivist scholars of nationalism (see Chatterjee 1991; Brubaker 1998, 2006; Calhoun 2007) and others who have theorized the notion of "everyday nationalism" (Billig 1995; Fox and Miller-Idriss 2008; Jones and Merriman 2009; Chandra 2012; Skey and Antonsich 2017). Furthermore, this analysis shows the antagonistic voices that try to define the nation and how they use the past and manipulate memory in order to achieve their ends (Hutchinson 2004). By analyzing not only the discourse but the historical context, I have shown that over the 19th century, the definition of the Irish nation changed from a Protestant nation to a Catholic one. Similarly, it took more than a century for the Lower-Canadian nation, defined by its French heritage and Catholicism, to transform into the Québécois nation defined by its language and its culture. By examining the various commemorative example of the rebellions, and through the comparison of historical material, it becomes clear that as a nation evolves, the myths it uses to legitimize its narratives need to follow. The changing definition of both the Irish and Québécois nations drastically affected the process of remembrance of the two rebellions, which are today their respective nations' founding myth. In sum, we see through this historiographical analysis the relative difficulty of remembering in times when historical events are not in phase with the national development.

Interestingly, the memory of the rebellions is again changing. In Northern Ireland, it was mobilized in 1998, during the signing of the Good Friday Agreements. If until then the rebellion represented a Catholic victory, the hope of peace in Northern Ireland allowed a rewriting of this national myth, finally recognizing the participation of and the alliance made with the Protestants (Bartlett, Keogh, and Whelan 2003). In a similar way, in Québec, the memory of the Patriotes now tends to be mobilized by the partisans 


\section{Defining National Memories}

of an ultraconservative, far right, branch of the nationalist movement, a traditionalist subdivision which considers itself as the "true descendants" of the patriots' heritage (Radio-Canada 2017). This again shows the close relationship between national development and the politics of remembrance.

\section{Bibliography}

Althusser, Louis. 1976. Positions. [Positions] Paris : Éditions sociales.

Andrews, Stuart. 2006. Irish Rebellion: Protestant Polemic, 1798-1900. Basingstoke, UK; New York: Palgrave Macmillian.

Anderson, Benedict. (1983) 2006. Imagined Communities: Reflections on the Origin and Spread of Nationalism. Revised ed. London; New York: Verso Books.

Assmann, Jan, and John Czaplicka. 1995. "Collective Memory and Cultural Identity." New German Critique 65: 125-33.

Barthes, Roland. 1966. 'Introduction à l'analyse structurale des récits' [Introduction to the structural analysis of narrative]. Communications 8(1): 1-27.

Bartlett, Thomas. 2014. “The Emergence of the Irish Catholic Nation, 1750-1850.” In The Oxford Handbook of Modern Irish History, edited by Alvin Jackson, 517-44. Oxford: Oxford University Press.

Bartlett, Thomas. 1992. The Fall and Rise of the Irish Nation: The Catholic Question, 16901830. Dublin: Gill and Macmillan.

Bartlett, Thomas, David Dickson, Dáire Keogh, and Kevin Whelan, eds. 2003. 1798: A Bicentenary Perspective. Dublin; Portland, OR: Four Courts.

Bédard, Théophile-Pierre. 1869. Histoire de cinquante ans [History of 150 years]. Québec : Éditions des presses à vapeur de Léger Brousseau.

Bergholz, Max. 2016. Violence As a Generative Force: Identity, Nationalism, and Memory in a Balkan Community. Ithaca, NY: Cornell University Press.

Bernard, Jean-Paul. 1983. Les Rébellions de 1837-1838: Les Patriotes du Bas-Canada dans la mémoire collective et chez les historiens [The Rebellions of 1837-1838 : Lower-Canadian patriots in the collective memory and among historians]. Montréal: Boréal Express.

Billig, Michael. 1995. Banal Nationalism. London; Thousand Oaks, CA: SAGE.

Bourgault, Pierre. 1966. Pierre Bourgault, discours sur la langue. [Pierre Bourgault : Discourse on language] Montréal. http://archives.radio-canada.ca/sante/langue_culture/clips/7518/.

Bric, Maurice J. 2016. “Catholicism and Empire: Ireland and Lower Canada, 1760-1830.” In Ireland and Quebec: Multidisciplinary Perspectives on History, Culture and Society, edited by Margaret Kelleher and Michael Kenneally, 32-46. Dublin: Four Courts Press.

Brubaker, Rogers. 2006. Ethnicity without Groups. Cambridge, MA: Harvard University Press.

Brubaker, Rogers. 1998. "Myths and Misconceptions in the Study of Nationalism" in The State of the Nation: Ernest Gellner and the Theory of Nationalism, edited by John A. Hall, 272-306. Cambridge: Cambridge University Press.

Chatterjee, Partha. 1991. “Whose Imagined Community?” Millennium 20(3): 521-5. 


\section{Journal of Nationalism, Memory \& Language Politics 16(1)}

Chandra, Kanchan. 2012. Constructivist Theories of Ethnic Politics. New York: Oxford University Press.

Calhoun, Craig J. 2007. Nations Matter: Culture, History, and the Cosmopolitan Dream. London; New York: Routledge.

Collins, Peter. 1999. "The Contest of Memory: The Continuing Impact of 1798 Commemoration." Eire-Ireland 34(2): 28-50.

Collins, Peter. 2004. Who Fears to Speak of '98'? Commemoration and the Continuing Impact of the United Irishmen. Belfast: Ulster Historical Foundation.

Ducharme, Michel. 2009. Le concept de liberté au Canada à l'époque des révolutions atlantiques (1776-1838) [The concept of liberty in Canada at the time of the Atlantic revolutions (1776-1838)]. Montréal; Kingston: McGill-Queen’s Press.

Englefiel, D. J. T. 1955. “The Irish Houses of Parliament in the Eighteenth Century.” Parliamentary Affairs 9(1): 57-64.

Foster, Roy. 2001. "Remembering 1798." In History and Memory in Modern Ireland, edited by Ian McBride, 67-94. Cambridge: Cambridge University Press.

Foucault, Michel. 2009. L'ordre du discours. [The order of discourse]. Paris: Gallimard.

Fox, Jon E., and Cynthia Miller-Idriss. 2008. "Everyday Nationhood." Ethnicities 8(4): 53663.

Hill, Jacqueline. 2001. "Irish Identities before and after the Act of Union." Radharc 2: 51-73.

Hobsbawm, Eric. (1983) 2012. The Invention of Tradition. Cambridge: Cambridge University Press.

Hutchinson, John. 1987. The Dynamics of Cultural Nationalism: The Gaelic Revival and the Creation of the Irish Nation State. London; Boston: Allen \& Unwin.

Hutchinson, John. 1994. Modern Nationalism. London: Fontana Press.

Hutchinson, John. 2004. Nations as Zones of Conflict. London: SAGE.

Johnson, Nuala C. 1994. "Sculpting Heroic Histories: Celebrating the Centenary of the 1798 Rebellion in Ireland.” Transactions of the Institute of British Geographers 19(1): 78-93.

Jones, Rhys, and Peter Merriman. 2009. "Hot, Banal and Everyday Nationalism: Bilingual Road Signs in Wales.” Political Geography 28(3): 164-73.

Joyce, James. (1922) 2006. Ulysse. [Ulysses]. Paris: Folio.

Kavanagh, Patrick F. 1880. A Popular History of the Insurrection of 1798: Derived from Every Available Written Record. Dublin: M. H. Gill \& Son. http://archive.org/details/apopularhistory00kavagoog.

Kubik, Jan, and Michael Bernhard. 2014. "A Theory of the Politics of Memory." In Twenty Years After Communism, edited by Michael Bernhard and Jan Kubik, 7-34. Oxford: Oxford University Press.

Landry, Bernard. 2001. "27 Novembre 2001 :allocution du Premier Ministre, M. Bernard Landry, lors de la présentation d'une motion sans préavis à l'Assemblée Nationale à l'occasion de La Fête Des Patriotes' [November 27, 2001: address by the Prime Minister, Mr. Bernard Landry, during the presentation of a motion without notice to the National Assembly on the occasion of La Fête Des Patriotes]. Québec : Assemblée Nationale du Québec. 


\section{Defining National Memories}

Levinger, Matthew, and Paula Franklin Lytle. 2001. "Myth and Mobilisation: The Triadic Structure of Nationalist Rhetoric." Nations and Nationalism 7(2): 175-94.

McCaffrey, Lawrence J. 2015. Daniel O'Connell and the Repeal Year. Lexington : University Press of Kentucky.

Metzger, Jean-Paul. 2019. Le discours : Un concept pour les sciences de l'information et de la communication. [The discourse: a concept for the information and the communication sciences]. London: ISTE Group.

Misztal, Barbara A. 2003. Theories of Social Remembering: Theorizing Society. Maidenhead : Open University Press.

Morin, Augustin-Norbert. 1825. «Lettre à l'honorable Edward Bowen, écuyer, un des juges de la cour du banc du roi de sa majesté pour le district de Québec.» [Letter to the Honorable Edward Bowen, Écuyer, one of the judges of Her Majesty's Court of King's Bench for the district of Quebec]. Québec : Répertoire du patrimoine culturel du Québec.

Musgrave, Richard. 1802. Memoirs of the Different Rebellions in Ireland. Dublin: Robert Marchbank.

Oakes, Leigh. 2001. Language and National Identity: Comparing France and Sweden. Amsterdam: John Benjamins.

O'Connell, Daniel. 2017. A Collection of Speeches Spoken by Daniel O'Connell, edited by Richard Sheil. Dublin : John Cumming.

Papineau, Louis Joseph. 1998. Louis-Joseph Papineau : Un demi-siècle de combats : interventions publiques. [Louis-Joseph Papineau: half a century of fighting: public interventions], edited by Claude Larin and Yvan Lamonde. Montréal : Éditions Fides.

Pigeon, Mathieu. 2017. «Les relations Québec-Canada.» [Quebec-Canada relations]. Montreal : Musée McCord.

Qulggin, R. George. 1938. "Religion and Politics." The Globe and Mail, July 23, 1938, p. 6.

Radio-Canada. 2017. "Retour en images sur la journée de manifestation à Québec " [Images of today's manifestation in Québec], August 21, 2017, https://ici.radio-canada.ca/nouvelle/1051409/meute-retour-images-journee-manifestation-quebec.

Rigney, Ann. 2018. "Remembrance as Remaking: Memories of the Nation Revisited." Nations and Nationalism 24(2): 240-57.

Skey, Michael, and Marco Antonsich (eds.). 2017. Everyday Nationhood: Theorising Culture, Identity and Belonging after Banal Nationalism. London: Palgrave Macmillan.

Smith, Anthony D. 1995. "Gastronomy or Geology? The Role of Nationalism in the Reconstruction of Nations." Nations and Nationalism 1(1): 3-23.

St-Jean, France. 2009a. "Images du patriote: objets commémoratifs, intentions variables. » [Images of the patriot: commemorative objects, variable intentions]. PhD thesis (Université du Québec à Montréal).

St-Jean, France. 2009b. 'Saint-Denis-sur-le-Richelieu, lieu de mémoire des rébellions de 18371838: Miroir d'une affirmation canadienne-française' [Saint-Denis-sur-le-Richelieu:, memory sites of the 1837-1838 rebellions: mirror of a French-Canadian affirmation]. In Entre lieux et mémoire: l'inscription de la francophonie canadienne dans la durée [Between places and memory: the inscription of Canadian Francophonie in time], edited by Anne Gil- 


\section{Journal of Nationalism, Memory \& Language Politics 16(1)}

bert, Michel Bock, and Joseph-Yvon Thériault, 55-92. Ottawa: Les Presses de l'Université d'Ottawa.

Thériault, Joseph Yvon. 2007. "Langue et politique au Québec: entre mémoire et distanciation. " [Language and politics in Quebec: between memory and distancing]. Hérodote 126(3): 115-27.

Union Nationale. 1935. "Manifeste de l'Union Nationale (1935). " [Manifesto of the National Union (1935)]. http://bilan.usherbrooke.ca/voutes/callisto/dhsp3/lois/Manifeste_ Union_Nationale.html.

Viggiani, Elisabetta. 2014. Talking Stones: The Politics of Memorialization in Post-Conflict Northern Ireland. New York: Berghahn Books.

Wolfe Tone, Theobald. (1796) 2010. An Address to the People of Ireland on the Present Important Crisis. Charleston: BiblioLife.

Wolfe Tone, Theobald. 1791. An Argument on Behalf of the Catholics of Ireland. Belfast: Gale ECCO, Print Editions.

Zubrzycki, Geneviève. 2016. Beheading the Saint: Nationalism, Religion, and Secularism in Quebec. Chicago; London: University of Chicago Press. 